\title{
Shortened action of succinylcholine in individuals with cholinesterase $\mathrm{C}_{5}$ isozyme
}

To test the possibility that individuals with and without plasma cholinesterase $C_{5}$ isozyme have differences in neuromuscular sensitivity to succinylcholine chloride, we examined the effects of succinylcholine in these two groups of patients. Sera from 491 adult patients were examined for presence of the plasma cholinesterase $C_{s}$ isozyme by use of electrophoresis with polyacrylamide; 24 were positive for the $C_{5}$ isozyme. Plasma cholinesterase activity and duration of action of succinylcholine were measured in $12 C_{5}$ positive patients and $18 C_{5}$ negative patients, all of whom had the normal cholinesterase genotype. $C_{5}$ positive patients had 30.1 per cent higher mean plasmo cholinesterase activity than $C_{5}$ negative patients. The duration of neuromuscular blockade, measured by the first witch height evoked by train-of-four stimulation, was significantly shorter in $C_{5}$ positive patients than $C_{5}$ negative patients. The $C_{5}$ positive individuals had shorter duration of action of succinylcholine than $C_{5}$ negative individuals.

Key words

ENZYMES: cholinesterases, isoenzyme; NEUROMUSCULAR RELAXANTS: succinylcholine; TECHNIQUES: electrophoresis, polyacrylamide gel.

From the Department of Anesthesiology, Toyama Medical and Pharmaceutical University, 2630 Sugitani, Toyama-shi, 930-01, Japan.
Succinylcholine chloride ( $\mathrm{SCh}$ ) is hydrolysed by plasma cholinesterase (ChE, EC 3.1.1.8). ${ }^{\prime}$ It is generally accepted that the short duration of action of succinylcholine is due to a rapid enzymatic hydrolysis by $\mathrm{ChE}$. The duration of action of SCh has been shown to be dependent on the activity of plasma $\mathrm{ChE}^{2}$ ChE was electrophoretically separated to four isoenzymes $C_{1}, C_{2}, C_{3}$ and $C_{4}$. In addition to these four, a fifth slower moving component was found in some individuals, who were labelled $\mathrm{C}_{5}$ positive $\left(\mathrm{C}_{5}{ }^{+}\right)$variants, while individuals who lack the component were labelled $\mathrm{C}_{5}$ negative $\left(\mathrm{C}_{5}{ }^{-}\right)$variants. ${ }^{3}$ Sera containing $\mathrm{C}_{5}$ usually have relatively high $\mathrm{ChE}$ activity. ${ }^{4}$ Though it is logical to speculate that $\mathrm{C}_{5}{ }^{+}$individuals have a shorter duration of action of succinylcholine than those who are $\mathrm{C}_{5}^{-}$, no investigation has been reported concerning the role of the $\mathrm{ChE}$ isozyme in determining responsiveness to succinylcholine.

The purpose of present study was to determine whether patients with the $C_{5}$ isozyme have a shortened duration of action of succinylcholine and to quantify the relationship between duration of succinylcholine neuromuscular blockade and the plasma $\mathrm{ChE} \mathrm{C}_{5}$ isozyme.

\section{Methods}

Four hundred and ninety one adult patients, 267 men and 224 women, undergoing elective surgery were studied. Informed consent was obtained from each patient and the study was approved by the hospital ethics committee. Blood samples for detection of the $\mathrm{ChE} \mathrm{C}_{5}$ component were withdrawn at the preanaesthetic examination. Presence or absence of the $\mathrm{ChE} \mathrm{C}_{5}$ component was established by electrophoresis. Electrophoresis of sera was performed using a miniaturized electrophoretic appara- 
tus which was custom-made, according to specifications previously published. ${ }^{5}$ Electrophoresis was carried out essentially as described by Davis. ${ }^{6}$ (See Appendix for details.) Scanning profiles were obtained after applying the gels to a densitometer.

$\mathrm{ChE}$ activity was assayed spectrophotometrically in a Hitachi 200-20 recording spectrophotometer by the method of Kalow and Lindsay ${ }^{7}$ which is based on the rate of hydrolysis of benzoylcholine in $\mathrm{M} / 15$ phosphate buffer $\mathrm{pH} 7.4$ at $25^{\circ} \mathrm{C}$ which is followed by decrease in absorbance at $240 \mathrm{~nm}$. Serum at a dilution of 1:50 was used as the source of enzyme, the final dilution in the reaction mixture being 1:100. Dibucaine and fluoride numbers were determined as described by Kalow and Genest $t^{8}$ and Harris and Whittaker ${ }^{9}$ respectively.

Eighteen $\mathrm{C}_{5}$ negative patients who were randomly selected from the $C_{5}$ negative patients of ASA physical status $I$ or II and all of $12 \mathrm{C}_{5}$ positive patients of ASA physical status I or II (all of whom had normal ChE genotypes (dibucaine number and fluoride number)), were entered in the study of neuromuscular blockade and measurement of $\mathrm{ChE}$ activity. For all tests of $\mathrm{ChE}$ activity, dibucaine and fluoride numbers, and monitoring of neuromuscular blockade, the observers were unaware of the $\mathrm{C}_{5}{ }^{-}$ and $\mathrm{C}_{5}{ }^{+}$identity of individual patients.

Premedication consisted of $0.4-0.5 \mathrm{mg}$ atropine IM and $50 \mathrm{mg}$ hydroxyzine IM 45-60 min before induction of anaesthesia. A blood sample to be used for measurement of $\mathrm{ChE}$ activity was withdrawn, and an intravenous infusion was started when the patient arrived in the operating room. Anaesthesia was induced with thiamylal $4-5 \mathrm{mg} \cdot \mathrm{kg}^{-1}$ and maintained with 66 per cent nitrous oxide in oxygen and additional thiamylal. Respiration was assisted, if required, but hyperventilation was avoided by measuring arterial blood gases periodically, in addition to serum electrolytes, and serum $\mathrm{pH}$. Body temperature was measured by rectal probe inserted before induction of anaesthesia.

After induction of anaesthesia, the ulnar nerve was stimulated at the wrist with a series of four supramaximal single stimuli (square wave pulses of $0.2 \mathrm{msec}$ duration) delivered at $0.1 \mathrm{~Hz}$ (train-offour) from a peripheral nerve stimulator (Myotest, Biometer Ltd., Denmark) using surface electrodes. The evoked force of contraction of the adductor pollicis was measured and recorded using a force transducer and a neuromuscular function analyzer

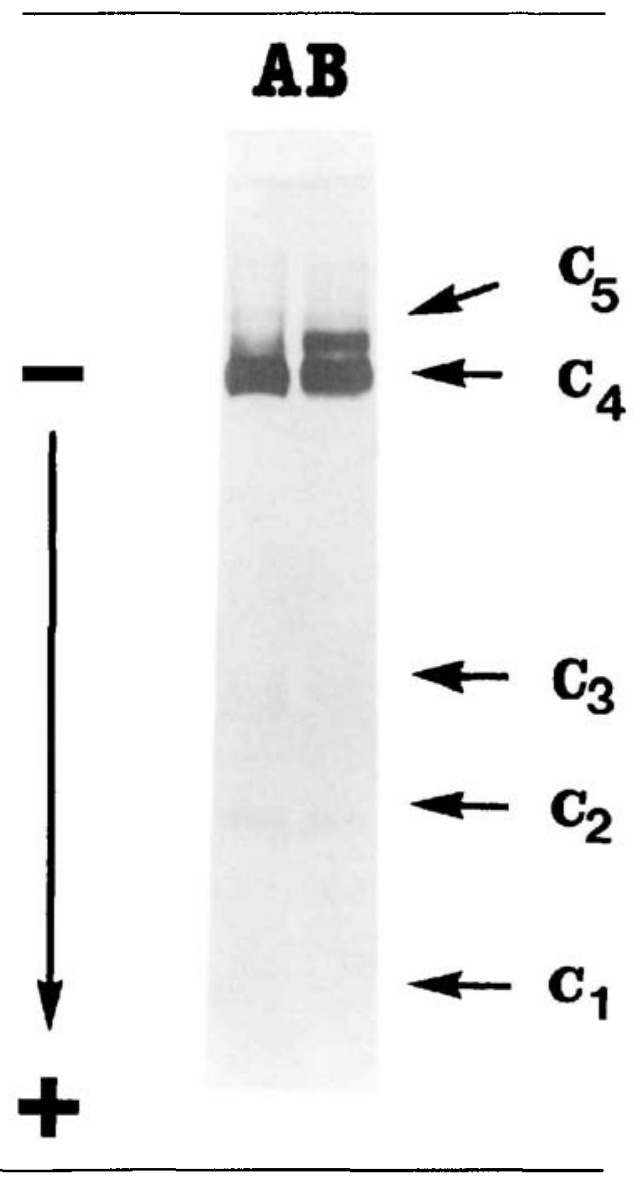

FIGURE 1 Polyacrylamide (seven per cent) gel electrophoresis of plasma cholinesterase of individuals without $C_{5}$ isozyme (A) and with $C_{5}$ isozyme (B). (A) demonstrates four isozymes of cholinesterase $C_{1}, C_{2}, C_{3}$, and $C_{4}$. $A$ fifth slower-moving component, $C_{5}$, is seen in (B) in addition to four components.

(Myograph 2000, Biometer Ltd., Denmark) as described by Viby-Mogensen. ${ }^{10}$

When the response to the train-of-four stimulation was stable, the height of the first twitch of the train was taken as the standard control (control twitch height). Succinylcholine, $40 \mathrm{mg} / \mathrm{m}^{2}$ body surface area, was given intravenously as quickly as possible. Monitoring of neuromuscular transmission was continued after succinylcholine administration, at least until the height of the first twitch of the train had returned to the control twitch height. The time from injection of succinylcholine to 20 , 


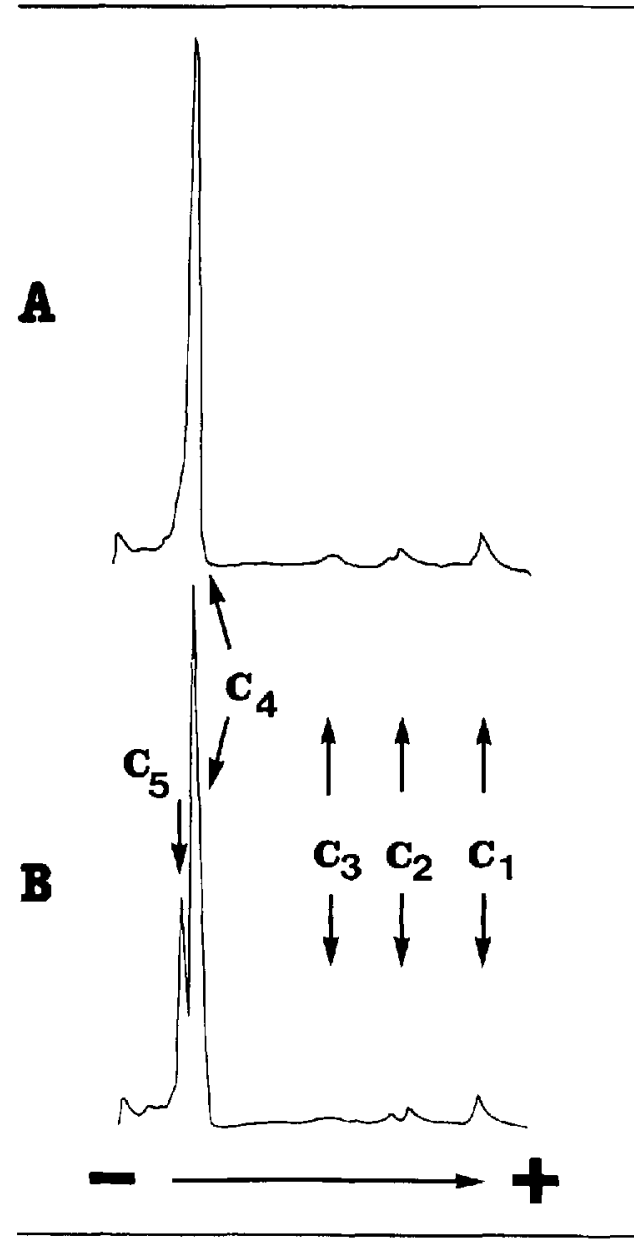

FIGURE 2 Gel scanning of electrophoretic profiles shown in Fig. 1 by densitometer. (A) $C_{1}, C_{2}, C_{3}$ and $C_{4} ;$ (B) $C_{1}, C_{2}$, $C_{3}, C_{4}$ and $C_{5}$. The cathode is to the right in both panels.
50 , and 80 per cent recovery of control twitch height were determined in each case.

Statistical significance was estimated with an unpaired t-test.

\section{Results}

Electrophoresis of sera of patients demonstrated zymograms of $\mathrm{ChE}$ as in Figure 1. Four components of senum cholinesterase are shown in lane $\mathrm{A}$. These isozymes have been designated $C_{1}, C_{2}, C_{3}$, and $C_{4}$ from cathode to anode. A fifth, slower-moving component can be seen clearly in lane $B$, in addition to the four components demonstrated in lane $A$. This component was named the $\mathrm{C}_{5}$ component by Harris et $a l^{3}$ It has been shown that the $\mathrm{C}_{4}$ band contributes the greatest portion of ChE activity, and the $\mathrm{C}_{5}$ component - if present - contains the second largest portion of $\mathrm{ChE}$ activity in the $\mathrm{C}_{5}{ }^{+}$enzyme as demonstrated by densitometry (Figure 2).

Both groups of patients were comparable with respect to sex, age, weight, height, and body surface area (Table I). Twenty-four of the 491 (4.9 per cent) patients studied were positive for the $C_{5}$ isozyme. Nine were positive for the $\mathrm{ChE} \mathrm{C}_{5}$ isozyme among the 267 males, and 15 of 224 females were $\mathrm{ChE}_{5}$ positive.

Plasma cholinesterase activity in the $\mathrm{C}_{5}{ }^{+}$group was significantly higher than the $\mathrm{C}_{5}{ }^{-}$group. $\mathrm{Pa}$ tients whose sera contain the $C_{5}$ component had 30.1 per cent more $\mathrm{ChE}$ activity than those without this component. Dibucaine and fluoride numbers were within normal limits in all the patients who had ChE activity measured (Table II).

The pattern of neuromuscular blockade was characteristic of a depolarizing block in all cases. The duration of neuromuscular blockade by succinylcholine was significantly shorter in $\mathrm{C}_{5}{ }^{+}$patients than $\mathrm{C}_{5}{ }^{-}$patients (Table III). Average times

TABLE I Patients' profile (Mean \pm SEM)

\begin{tabular}{lcccl}
\hline Group & Age (years) & Height $(\mathrm{cm})$ & $\begin{array}{l}\text { Body } \\
\text { weight }(\mathrm{kg})\end{array}$ & $\begin{array}{l}\text { Body } \\
\text { surface } \\
\text { area }\left(\mathrm{m}^{2}\right)\end{array}$ \\
\hline $\mathrm{C}_{5}^{-}$ & $44.0 \pm 2.72$ & $159.3 \pm 1.06$ & $55.3 \pm 2.19$ & $1.57 \pm 0.031$ \\
$\mathrm{n}=18$ & $47.0 \pm 3.38$ & $157.4 \pm 2.88$ & $55.7 \pm 2.28$ & $1.57 \pm 0.044$ \\
$\mathrm{C}_{3}^{+}$ & & & & \\
$\mathrm{n}=12$ & &
\end{tabular}


TABLE II Cholinesterase activity, dibucaine numbers and fluoride numbers (Mean \pm SEM)

\begin{tabular}{llll}
\hline & $\begin{array}{l}\text { ChE } \\
\text { activity }(I U)\end{array}$ & $\begin{array}{l}\text { Dibucaine } \\
\text { numbers }\end{array}$ & $\begin{array}{l}\text { Fluoride } \\
\text { numbers }\end{array}$ \\
\hline $\mathrm{C}_{5}^{-}$ & $750.8 \pm 26.9$ & $78.5 \pm 0.74$ & $62.2 \pm 1.02$ \\
$\mathrm{n}=18$ & & $77.8 \pm 0.94$ & $63.3 \pm 0.90$ \\
$\mathrm{C}_{5}^{+}$ & $976.8 \pm 58.2^{*}$ & & \\
$\mathrm{n}=12$ & & &
\end{tabular}

*Significantly different from $\mathrm{C}_{5}{ }^{-}$group $(\mathrm{p}<0.01)$.

TABLE III Times to recovery of twitch height to $20 \%, 50 \%$ and $80 \%$ of control twitch height after intravenous administration of $40 \mathrm{mg} / \mathrm{m}^{2} \mathrm{BSA}$ succinylcholine (Mean $\pm \mathrm{SEM}$ )

\begin{tabular}{llll}
\hline & $\begin{array}{l}\text { 20\% Twitch } \\
\text { height }(\mathrm{sec})\end{array}$ & $\begin{array}{l}\text { S0\% Twitch } \\
\text { height (sec) }\end{array}$ & $\begin{array}{l}80 \% \text { Twitch } \\
\text { height (sec) }\end{array}$ \\
\hline $\mathrm{C}_{5}^{-}$ & $886.7 \pm 61.5$ & $1105.3 \pm 85.3$ & $1409.7 \pm 139.4$ \\
$\mathbf{n}=18$ & & $787.5 \pm 78.5^{*}$ & $916.3 \pm 93.5 \dagger$ \\
$\mathrm{C}_{5}^{+}$ & $670.8 \pm 68.2^{*}$ & & \\
$\mathbf{n}=12$ & & &
\end{tabular}

*Significantly different from $\mathrm{C}_{5}^{-}$group $(\mathrm{p}<0.05)$.

+ Significantly different from $C_{5}^{-}$group $(p<0.02)$.

to recovery of twitch height to 20,50 , and 80 per cent of control twitch height in $\mathrm{C}_{5}{ }^{+}$individuals were $75.7,71.2,65.0$ per cent of corresponding value in $\mathrm{C}_{5}^{-}$individuals respectively.

\section{Discussion}

Harris et $a l^{3}$ described the appearance and enzymatic behaviour of serum ChE in normal serum as seen after two dimensional electrophoresis, first on paper and then on starch gel. Four components of serum ChE activity were found in the gels, corresponding to at least four isozymes which have been designated as $\mathrm{C}_{1}, \mathrm{C}_{2}, \mathrm{C}_{3}$, and $\mathrm{C}_{4}$, according to the decreasing order of mobility toward the anode. The slowest component $\left(C_{4}\right)$ is the major enzyme, containing most of the serum ChE activity. Harris et al. found a fifth slower-moving component, in a few sera. This component was designated the $\mathrm{C}_{5}$ component. Our experiments clearly demonstrate that the $\mathrm{C}_{5}$ isozyme can be separated from other isozymes of $\mathrm{ChE}$ by electrophoresis with polyacrylamide. Harris et al. ${ }^{11}$ provided evidence that the gene which determines the occurrence of $\mathrm{C}_{5}$ is non-allelic to the genes on $E_{1}$ locus which control the bands $\mathrm{C}_{1}-\mathrm{C}_{4}$. Robson et al. ${ }^{12}$ supported this hypothesis. This second gene has been designated the $\mathrm{E}_{2}^{+}$gene. ${ }^{13}$

The incidence of the $\mathrm{C}_{5}$ variant in our patient population (all Japanese) was 4.9 per cent. The frequency of the $C_{5}$ variant in various populations was found to vary from 0.3 per cent to 10.1 per cent by Steegmüller. ${ }^{14}$ She also reviewed the incidence of the $C_{5}$ variant in various populations as found by others, with values of 0 to 29 per cent reported. The calculated incidence of the $C_{5}$ variant was 9.4 per cent among Mongoloids (included 47 Koreans and 81 Thais). The number of samples tested was likely too few to give a reliable incidence. A possible explanation for the variations noted is that electrophoretic methods used by most authors are not sensitive enough to detect all patients with the $\mathrm{C}_{5}{ }^{+}$ phenotypes. Simpson ${ }^{15}$ demonstrated that a polyacrylamide gel electrophoretic system ( 2.5 per cent acrylamide spacer gel, pH6.7; seven per cent separating gel, $\mathrm{pH} 8.9$ ) was able to detect 25 per cent more $\mathrm{C}_{5}{ }^{+}$individuals than a 15 per cent starch gel system at $\mathrm{pH} 5.3$. However Singh et al. ${ }^{16}$ maintained that in their material the method described by Simpson did not help to detect any misclassification produced by the starch gel method.

The results of this study show that $C_{5}$ positive variants have 30 per cent more plasma ChE activity than those without this component. This is in accordance with the results of Harris et $a l,{ }^{4}$ who reported that subjects whose sera contained the $\mathrm{C}_{5}$ component usually have 30 per cent more plasma cholinesterase activity than those without this component.

The duration of action of succinylcholine was about 30 per cent less in $\mathrm{C}_{5}{ }^{+}$individuals than in $\mathrm{C}_{5}-$ individuals, when it was administered on the basis of body surface area. Earlier studies have examined the correlation between the $\mathrm{ChE}$ level and duration of action of succinylcholine. Some found good correlations between the esterase level and duration of apnoea ${ }^{17-24}$ while others found only partial correlation or no correlation. ${ }^{25.26}$ In none of these studies was neuromuscular function monitored. In addition, few of the studies investigated the $\mathrm{ChE}$ phenotype and none determined the $\mathrm{ChE} \mathrm{C}_{5}$ isozyme.

Viby-Mogensen ${ }^{2}$ reported that for patients with the geotypically normal enzyme the duration of succinylcholine action measured by the duration 
of apnoea and the time to 100 per cent recovery of twitch height (train-of-four) increased with the decreasing plasma $\mathrm{ChE}$ activity. He did not investigate the $\mathrm{ChE}$ isozyme for detection of the $\mathrm{C}_{5}$ variant, though he determined dibucaine, fluoride, chloride, scoline, and urea numbers. Neitlich ${ }^{27}$ reported a genetic variant that increased the serum $\mathrm{ChE}$ two to three times the normal mean value with the appearance of a slow-moving band on zymograms obtained by disc-electrophoresis with acrylamide gels as the supporting medium. This variant was associated with resistance to succinylcholine in grip strength. Yoshida and Motulsky ${ }^{28}$ showed the increased enzyme activity of the variant described by Neitlich could be attributed to an increase in the number of enzyme molecules. They concluded that the variant enzyme has approximately the same specific enzyme activity as normal and that the extra enzyme component of the variant plasma is structurally different from the $\mathrm{C}_{5}$ enzyme component. They named the variant $E$. cynthiana.

Blitt et $a .^{29}$ showed no correlation between plasma ChE activity and duration of paralysis from succinylcholine using single-twitch nerve stimulation. This is probably because Blitt's patients showed only minor variations in enzymatic activity. High plasma ChE activity was detected in two German families by Delbrück et al. ${ }^{30}$ They $^{31}$ showed that the ChE of the propositi exhibited isozyme separation patterns in polyacrylamide electrophoresis as well as in electrofocusing which were different from those of $\mathrm{ChE}$ from normal persons, but no differences could be seen with respect to the $\mathrm{Km}$ for substrates or the inhibition by dibucaine, fluoride or succinylcholine.

Scott et $a l^{32}$ showed the properties of the $\mathrm{C}_{5}{ }^{+}$ enzyme to differ from the principal serum $\mathrm{ChE}$ in only minor ways. Muensch et al. ${ }^{33}$ observed no difference at esteratic site of the enzyme with $C_{5}$ component from the normal enzyme without $C_{5}$. Therefore the difference in sensitivity to succinylcholine between $\mathrm{C}_{5}{ }^{-}$and $\mathrm{C}_{5}{ }^{+}$variants probably results from the difference in quantity of $\mathrm{ChE}$ activity.

The results of our study indicate that the $\mathrm{ChE} \mathrm{C}_{5}$ isozyme, a genetic factor determined by the presence of the $\mathrm{E}_{2}{ }^{+}$gene, contributes to decreased neuromuscular sensitivity to succinylcholine.

\section{Appendix}

Electrophoresis was carried out in seven per cent polyacrylamide gels for two hours at a constant current of $20 \mathrm{~mA}$. The running gel buffer was $187.5 \mathrm{mM}$ Tris- $\mathrm{HCl}$ (pH 8.8), the stacking gel buffer was $125 \mathrm{mM}$ Tris-HCl ( $\mathrm{pH} 6.8)$, and electrode buffer was $12.5 \mathrm{mM}$ Tris-glycine ( $\mathrm{pH} 8.3$ ). After electrophoresis, the gels are washed in three changes of $125 \mathrm{mM}$ phosphate buffer at $\mathrm{pH} 6.8$ for $10 \mathrm{~min}$ each. Then the gels are incubated in a reaction mixture consisting of $50 \mathrm{ml}$ of $125 \mathrm{mM}$ phosphate buffer at $\mathrm{pH} 6.8,1 \mathrm{ml}$ of one per cent $\alpha$-naphthyl acetate in acetone solution, and $100 \mathrm{mg}$ of fast violet B salt for $30 \mathrm{~min}$ at $37^{\circ} \mathrm{C}$. After incubation the stained gels are washed in running water.

\section{Acknowledgement}

The author thanks Dr. Z. Ogita for constructive criticism, Dr. K. Momoi and Dr. T. Masuda for excellent technical assistance, anaesthesia and surgical colleagues and operating room staff for their cooperation, and Dr. Y. Ito for spiritual support.

\section{References}

1 Nomenclature Committee of the International Union of Biochemistry. Enzyme Nomenclature 1978. New York: Academic Press, 1979; 235.

2 Viby-Mogensen J. Correlation of succinylcholine duration of action with plasma cholinesterase activity in subjects with the genotypically normal enzyme. Anesthesiology 1980; 53: 517-20.

3 Harris H, Hopkinson DA, Robson EB. Two-dimensional electrophoresis of pseudocholinesterase components in normal human serum. Nature 1962; 196: 1296-8.

4 Harris H, Hopkinson DA, Robson EB, Whittaker M. Genetical studies on a new variant of serum cholinesterase detected by electrophoresis. Ann Hum Genet 1963; 26: 359-82.

5 Ogita Z, Markert CL. A miniaturized system for electrophoresis on polyacrylamide gels. Analytical Biochemistry 1979; 99: 233-41.

6 Davis BJ. Disc electrophoresis. П. Method and application to human serum proteins. Ann NY Acad Sci 1964; 121: 404-27.

7 Kalow W, Lindsay HA. A comparison of optical and manometric methods for the assay of human serum cholinesterase. Can J Biochem 1955; 33: 56874. 
8 Kalow W, Genest $K$. A method for the detection of atypical forms of human serum cholinesterase. Determination of dibucaine numbers. Can J Biochem Physiol 1957; 35: 339-46.

9 Harris $H$. Whittaker $M$. Differential inhibition of human serum cholinesterase with fluoride: recognition of two new phenotypes. Nature 1961; 191: 469-98.

10 Viby-Mogensen $J$. Clinical assessment of neuromuscular transmission. $\mathrm{Br}$ J Anaesth 1982; 54: 209-22.

11 Harris H, Robson EB, Glen-Bott AM, Thornton JA. Evidence for non-allelism between genes affecting human serum cholinesterase. Nature 1963; 200: 1185-7.

12 Robson $E B$, Harris $H$. Further data on the incidence and genetics of the serum cholinesterase phenotype $\mathrm{C}_{5}{ }^{+}$. Ann Hum Genet 1966; 29: 403-8.

13 Motulsky AG. Pharmacogenetics. Prog Med Genet 1964; 3: 49-74.

14 Steegmüller $H$. On the geographical distribution of pseudocholinesterase variants. Humangenetic 1975; 26: 167-85.

15 Simpson NE. Polyacrylamide electrophoresis used for the detection of $\mathrm{C}_{5}{ }^{+}$cholinesterase in Canadian Caucasians, Indians and Eskimos. Am J Hum Genet 1972; 24: 317-20.

16 Singh S, Saternus K, Munsch H, Altland K, Goedde $H W$, Eriksson A. Pseudocholinesterase polymorphism among Ålanders (Finno-Swedes), Maris (Cheremisses, USSR) and Greenland Eskimos, and the segregation of some $E_{1}$ and $E_{2}$ locus types in Finnish Lapp families. Hum Hered 1974; 24 : 35262.

17 Bourne JG, Collier HOJ, Somers GF. Succinylcholine (succinylcholine). Muscle-relaxant of short action. Lancet 1952; 1: 1225-9.

18 Evans FT, Gray PWS, Lehmann H, Silk E. Sensitivity to succinylcholine in relation to serumcholinesterase. Lancet 1952; 1: 1229-30.

19 Evans FT, Gray PWS, Lehmann H, Silk E. Effect of pseudocholinesterase level on action of succinylcholine in man. Br Med J 1953; 1: 136-8.

20 Stovner $J$, Lind B. Succinylcholineapnea and serum cholinesterase. Nord Med 1954; 52: 1223-5.

21 Borders RW, Stephen CR, Nowill WK, Martin R. The interrelationship of succinylcholine and the blood cholinesterase during anesthesia. Anesthesiology 1955; 16: 401-22.
22 Kalow W, Gunn DR. The relation between dose of succinylcholine and duration of apnea in man. $J$ Pharmacol Exp Ther 1957; 120: 203-14.

23 Stoddart JC. The suxamethonium-pseudocholinesterase relationship. Br J Anaesth 1960; 32: 466-9.

24 Hodges $R J H$, Harkness $J$. Suxamethonium sensitivity in health and disease. Br Med J 1954; 2 : 18 22.

25 Foldes FF, Swerdlow $M$, Lipschitz E, Van Hees GR, Shanor SP. Comparison of the respiratory effects of suxamethonium and suxethonium in man. Ancsthesiology 1956; 17: 559-68.

26 Hunter AR. Prolongation of the action of suxamethonium. Anaesthesia 1966; 21: 337-45.

27 Neitlich $H W$. Increased plasma cholinesterase activity and succinylcholine resistance: a genetic variant. J Clin Invest 1966; 45: 380-7.

28 Yoshida A, Motulsky AG. A pseudocholinesterase variant (E Cynthiana) associated with elevated plasma enzyme activity. Am J Hum Genet 1969; 21: 486-98.

29 Blitt CD, Petty WC, Alberternst EE, Wright BJ. Correlation of plasma cholinesterase activity and duration of action of succinylcholine during pregnancy. Anesth Analg 1977; 56: 78-83.

30 Delbrück A, Henkel E, Kuschel K. Genetisch bedingte erhöhte Aktivität der. Cholinesterase im Serum. J Clin Chem Clin Biochem 1977; 15: 149.

31 Delbrück A, Henkel E. A rare genetically determined variant of pseudocholinesterase in two German families with high plasma enzyme activity. Eur J Biochem 1979; 99: 65-9.

32 Scott EM, Powers PF. Properties of the $\mathrm{C} 5$ variant form of human serum cholinesterase. Am J Hum Genet 1974; 26: 189-94.

33 Muensch H, Yoshida A, Altland K, Jensen W, Goedde $H-W$. Structural difference at the active site of dibucaine resistant variant of human plasma cholinesterase. Am J Hum Genet 1978; 30: 302-7. 
Résumé

Afin de vérifier la possibilité que les individus avec ou sans plasma cholinesterase $C_{5}$ isoenzyme présentent des différences de sensibilité à la succinylcholine, on a examiné les effets de succinylcholine chez ces deux groupes de patients. Les sérums de 491 patients adultes ont été examinés pour la présence de plasma cholinesterase $C_{5}$ isoenzyme par électrophorèse avec le polyacrylamide; 24 étaient positifs pour le $C_{5}$ isoenzyme. L'activité du plasma cholinesterase et la durée d'action de la succinylcholine ont été mesurée chez 12 patients ayant un $C_{5}$ positif et 18 patients ayant un $C_{5}$ négatif tous ayant un génotype normal de cholinesterase. Les patients avec $C_{S}$ positif ont présenté une activité moyenne de la plasma cholinesterase 30.1 pour cent supérieur à celles qui ont présenté un $C_{5}$ négatif. La durée du bloc neuromusculaire mesurée par la hauteur du premier twitch évoqué par une stimulation d'une ondée de quatre était significativement plus courte chez les patients ayant un $C_{5}$ positif que ceux qui ont un $C_{5}$ négatif. Les individus ayant un $C_{5}$ positif ont présenté une durée d'action de la succinylcholine plus courte que ceux qui ont un $C_{5}$ négatif. 